\title{
A Study on Cooperative Banks in Himachal Pradesh with Special References to Lending Practices
}

\author{
Mukesh Kumar (Assistant Professor) \\ E.mail : mukesh2_jawali@yahoo.co.in \\ Dronacharya PG College of Education, Rait Kangra (H.P.)
}

\begin{abstract}
The banking industry has such a dramatic impact on the economy. It helps people start new businesses, fund new lines of equipment, and provide working capital management, allowing companies to hire new employees and introduce new products. Commercial banks play an important role in the financial system and the economy. They provide specialized financial services, which reduce the cost of obtaining information about both savings and borrowing opportunities. These financial services help to make the overall economy more efficient. The cooperative banking sector is one of the main partners of Indian banking structure, the cooperative banks have more reach to the rural India, through their huge network of credit societies in the institutional credit structure. The government of India passed the first cooperative credit societies act in 1904.The cooperative sector has played a key role in the economy of the country and always recognized as an integral part of our national economy. Cooperatives have ideological base, economic objects with social outlook and approach. The cooperative banks have to act as a friend, philosopher and guide to the entire cooperative structure. The study is based on the two main co-operative banks in the state of Himachal Pradesh (India).The study of the bank's performance along with the lending practices provided to the customers is herewith undertaken. The customer has taken more than one type of loan from the banks. Moreover they suggested that the bank should adopt the latest technology of the banking like ATMs, internet / online banking, credit cards etc. so as to bring the bank at par with the private sector banks.
\end{abstract}

Keywords: Cooperative Banks, Financial system, Cooperative credit societies act, Economy, Lending Practices, Credit Cards, Internet/Online Banking.

\section{INTRODUCTION}

The cooperatives which are the life blood of the Indian economy and the mechanism for any developmental programs. Especially in an agriculture and allied activities dominated rural sector, cooperative banks play a pivotal role in bolstering the common individual and financing his business and personal needs. These cooperative banks are traditionally centred on communities, localities and the work place groups and they essentially lend to small borrowers and small scale businesses. HP State cooperative bank and Kangra Central Cooperative banks offers a wide range of lending facilities' to meet local customer's diverse needs. These banks serve almost $80 \%$ of rural area need in HP.As at the end of March 2018, These banks provide lending services with their wide existence in the state of Himachal Pradesh. Kangra Cooperative banks has 216 branches operating in five districts of HP and HP state cooperative banks has 190 branches operating in six districts of Himachal Pradesh. The popularity of these banks increasing with their wide range of lending and quality services for their local customers.
While the co-operative banks in urban areas mainly finance various categories of people for selfemployment, industries, small scale units and home finance. While the co-operative banks in rural areas mainly finance agricultural based activities including farming, cattle, milk, hatchery, personal finance, etc. along with some small scale industries and selfemployment driven activities In Himachal Pradesh these banks provide most services such as savings and current accounts, safe deposit lockers, loan or mortgages to private and business customers, Educational loan, House loan etc.. For middle class users, for whom a bank is where they can save their money, facilities like Internet banking or phone banking is not very important. Although they are not better than private banks in terms of facilities provided, their interest rates are definitely competitive. However, unlike private banks, the documentation process is lengthy if not stringent and getting a loan approved quickly is rather difficult. The criteria for getting a loan from Cooperative banks are less stringent than for a loan from a commercial bank. Nowdays Cooperative banks are more focused on their quality and customer satisfaction services. 
Co-Operative Banking In Himachal Pradesh - In the year 1948, there was big societies of the banking facilities. The only four co-operative were in the state named as the Mandi Central Co-operative Bank, Mahasu Central Co-operative Bank, Chamba Central Co-operative Bank and Bank of Sirmour. In March 1954 the already existing four co-operative banks were merged into the H.P. State Co-operative Bank after reorganization of the state in PUNJAB and HARYANA and HIMACHAL PRADESH, some areas were transferred in November 1966 from Punjab to Himachal Pradesh. In these areas two Central Co-operative

Banks, one of them was Kangra Central Co-operative Bank and other was Jogindra Central Co-operative Bank.

Main Co-Operative Banking In H.P. (Overview in District Level)

\begin{tabular}{|l|l|l|}
\hline $\begin{array}{l}\text { Sr. } \\
\text { No. }\end{array}$ & $\begin{array}{l}\text { Name of } \\
\text { Cooperative Bank in } \\
\text { H.P }\end{array}$ & $\begin{array}{l}\text { District where Co- } \\
\text { operative } \\
\text { Operate } \\
\text { Banks }\end{array}$ \\
\hline $\mathbf{1}$ & $\begin{array}{l}\text { Himachal Pradesh } \\
\text { State Co-operative } \\
\text { Bank }\end{array}$ & $\begin{array}{l}\text { Shimla, Chamba, } \\
\text { Kinnour, Sirmour, } \\
\text { Mandi and Bilaspur }\end{array}$ \\
\hline $\mathbf{2}$ & $\begin{array}{l}\text { Kangra Central Co- } \\
\text { operative Bank }\end{array}$ & $\begin{array}{l}\text { Kangra, Kamirpur, Una and } \\
\text { Lahul \& Spiti }\end{array}$ \\
\hline
\end{tabular}

At present Himachal Pradesh has presence of quite a good number of Public sector banks, Private sector banks, Cooperative banks \& RRB and their ATM (Automated Teller Machine). The state had a network of 2092 branches and 1822 ATMs as on 31.06.2017. Out of which1220 branches of public sector banks, 136 branches of private sector banks, 496 of Cooperative banks and 247 of RRB. There are 1695 branches are in rural areas, 312 branches in Semi-urban areas and 98 branches in urban areas.

\section{OBJECTIVES OF THE STUDY}

1. To know the lending practices of cooperative banks in HP

2. To measure and compare the efficiency of Cooperative Banks in HP.

3. To study the impact of 'size' on the efficiency of the Cooperative Banks.
4. To suggest the appropriate measures to improve the efficiency of the Cooperative banks.

5. To know different type of loans preferred by different sets of customers.

6. To know the satisfaction level of the customers from Bank's lending policies.

\section{REVIEW OF LITERATURE}

Dutta and Basak (2008) suggested that Co-operative banks should improve their recovery performance, adopt new system of computerized monitoring of loans, implement proper prudential norms and organize regular workshops to sustain in the competitive banking environment.Chander and Chandel (2010) analyzed the financial efficiency and viability of HARCO Bank and found poor performance of the bank on capital adequacy, liquidity, earning quality and the management efficiency parameters. Mohi-ud-Din and Nazir (2010) stated that sound financial health of a bank is the guarantee not only toits depositors but is equally significant for the shareholders, employees and whole economy as well. In thispaper, an effort has been made to evaluate the financial performance of the two major banks in northern India.This evaluation has been done by using CAMEL Parameters, the latest model of financial analysis. Through thismodel, it is highlighted that the position of the banks, under study is satisfactory so far as their Capital adequacy, Assets quality, Management capabilities and Liquidity is concerned.Reddy and Prasad (2011) compared the performance of Regional Rural banks in Andhra Pradesh to check the viability of the banks. The concluded that Andhra Pragathi Gramin Bank is performing better than the other co-operative banks.

Sambath (2014) attempted in his study entitled "Growth and Progress of the Urban Cooperatives Banks in India" to analyse the growth and development of Urban Cooperatives Banks in India. He revealed in his study that the future of cooperatives banks in India is challenging because of cut throat competition from Public and Private sector banks. Public and Private sector banks concentrating on major expansion activities both are vertically and horizontally. The growth of cooperative banks depends on transparency in operation and

control, governance, customer centric policies, technology up gradation and efficiency.

Barwal and Kumar (2015)in their study entitled "Comparative Performance Evaluation of Himachal Pradesh Cooperative Bank And Kangra Central Cooperative Bank" has analysed the position of 


\section{Available online at www.ijrat.org}

shareholder fund, deposits mobilization and advances of Himachal Pradesh State Cooperative Bank \& Kangra Central Cooperative Bank and to study the financial \& operational of these two banks. They suggested that present study made an attempt to evaluate the both the banks from different angles so their relative performance can be gauged. After going through all the parameters it is concluded that Himachal Pradesh State Cooperative Bank had been able to increase the shareholders wealth during the period under study, as shareholder funds had

increased at a good rate during this period. Kangra Central Cooperative Bank is almost consistent in this parameters. In terms of deposit Kangra Central Cooperative Bank had performed very well its average growth during the period under study is almost $15 \%$ which is commendable.

\section{RESEARCH METHODOLOGY}

\subsection{Type of Research}

The study is Descriptive in nature in order to identify the lending practices of bank and determining customer's level of satisfaction. The method used was questionnaire and interview of the experienced loan officers.

\subsection{Collection of data:}

\subsubsection{Primary Data}

a. Observation Method

b. Interview

c. Structured Questionnaire

\subsubsection{Secondary Data}

a. Annual Bank's reports

b. Manual of instructions on loans and advances

c. Articles and Research Papers

d. Books and Internet

\subsection{Sampling Unit}

The Study population includes the customers of bank and Sampling Unit for Study was Individual Customer. 4.4 Sampling Size: 200 Respondents

\section{DATA ANALYSIS AND INTERPRETATION}

The data gathered through the questionnaires was tabulated, examined, and deciphered. Be that as it may, before beginning work of tabulation and analyzing, every one of the questionnaires was edited very carefully for completeness.

Table 1: Preferences of the customers for the loans



Figure 1: Preferences of the customers for the loans

Present study reveals that majority of the respondents have taken agricultural loans, house loans and less respondents prefer consumer, educational and vehicle loans. 
International Journal of Research in Advent Technology, Vol.7, No.1, January 2019

E-ISSN: 2321-9637

Available online at www.ijrat.org

Table 2: Range of the amount of loans

\begin{tabular}{|c|c|c|}
\hline Loan Amount & No. of Respondent & Percentage (\%) \\
\hline Less than 15000 & 4 & $8 \%$ \\
\hline $15,000-50,000$ & 6 & $12 \%$ \\
\hline $50,000-1 \mathrm{lac}$ & 10 & $20 \%$ \\
\hline More than 1 lac & 30 & $60 \%$ \\
\hline
\end{tabular}



Figure 2: Range of the amount of loans

Present Study reveals that $8 \%$ people prefer loan less than $15,000,12 \%$ respondents prefer 15,000 to $50,000,20 \%$ prefer $50,000-1$ lac and $60 \%$ of the respondents prefer more than 1 lac.

Table 3: Preferable term of loan

\begin{tabular}{|l|c|c|}
\hline Term of Loan & No. of respondent & Percentage (\%) \\
\hline Less than 1 year & 10 & $20 \%$ \\
\hline 1 to 3 years & 8 & $16 \%$ \\
\hline More than 3 years & 32 & $64 \%$ \\
\hline
\end{tabular}


International Journal of Research in Advent Technology, Vol.7, No.1, January 2019

E-ISSN: 2321-9637

Available online at www.ijrat.org

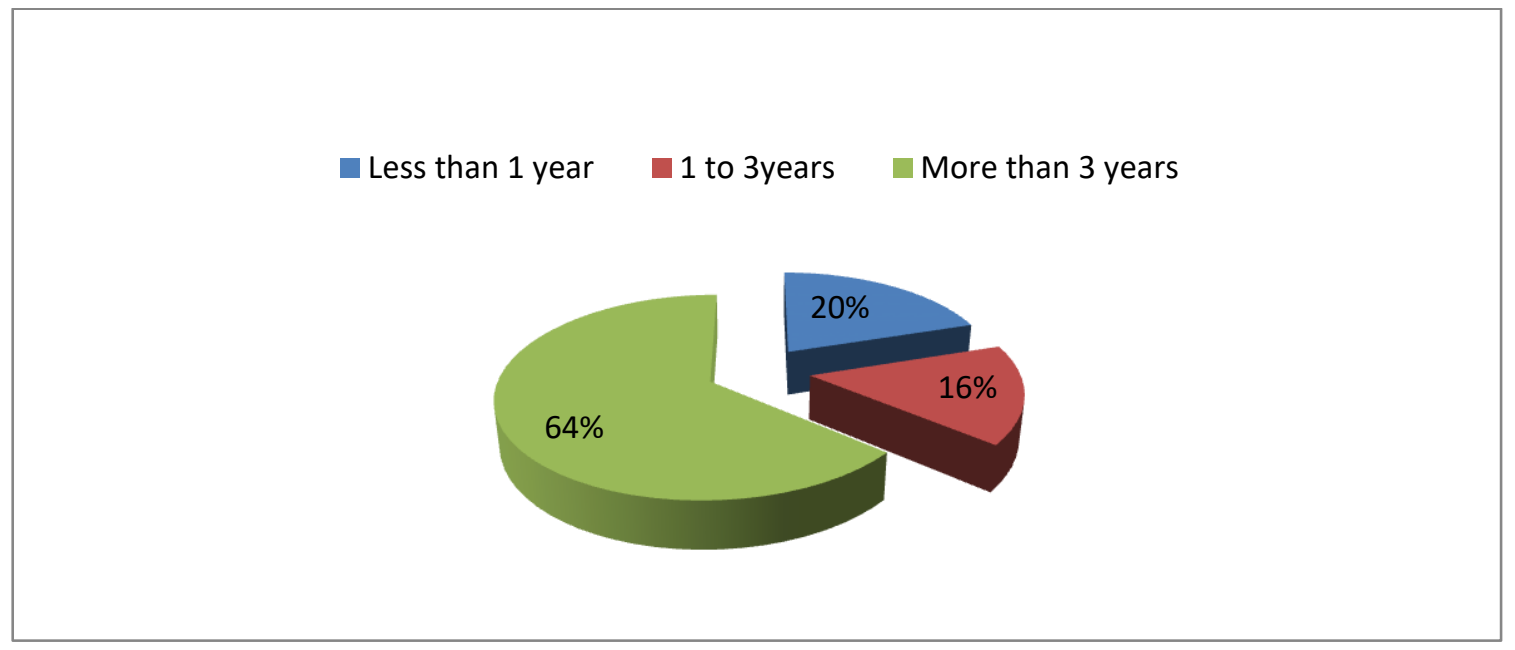

Figure 3: Preferable term of loan

Study shows that $64 \%$ respondents take loan for more than 3 years, $16 \%$ take loan for 1 to 3 years and $20 \%$ take loan for the period of less than 1 year.

Table 4: What prompted the customers to take loan from cooperative banks

\begin{tabular}{|l|l|l|}
\hline Reason for taking loan & No. of Respondent & Percentage (\%) \\
\hline Reasonable rate of interest & 4 & $8 \%$ \\
\hline Attractive schemes & 5 & $10 \%$ \\
\hline Less formalities & 15 & $30 \%$ \\
\hline Easy repayment & 25 & $50 \%$ \\
\hline Any other & 1 & $2 \%$ \\
\hline
\end{tabular}

Reasonable rate of interest $\square$ Attractive schemes $\square$ Less formalities $\square$ Easy repayment $\square$ Any other



Figure 4: What prompted the customers to take loan from cooperative banks 


\section{Available online at www.ijrat.org}

Study reveals that $50 \%$ take loan because banks provide easy payment,30\% take loans because of less formalities and other respondents take loan because of reasonable rate of interest, more schemes.

Table 5: Average time taken for the processing of the loan

\begin{tabular}{|l|l|l|}
\hline $\begin{array}{l}\text { Average time for processing of } \\
\text { loan }\end{array}$ & No. of respondent & Percentage (\%) \\
\hline Less than 1 week & 35 & $70 \%$ \\
\hline Between 1 to 2 weeks & 12 & $24 \%$ \\
\hline More than 2 weeks & 3 & $6 \%$ \\
\hline
\end{tabular}

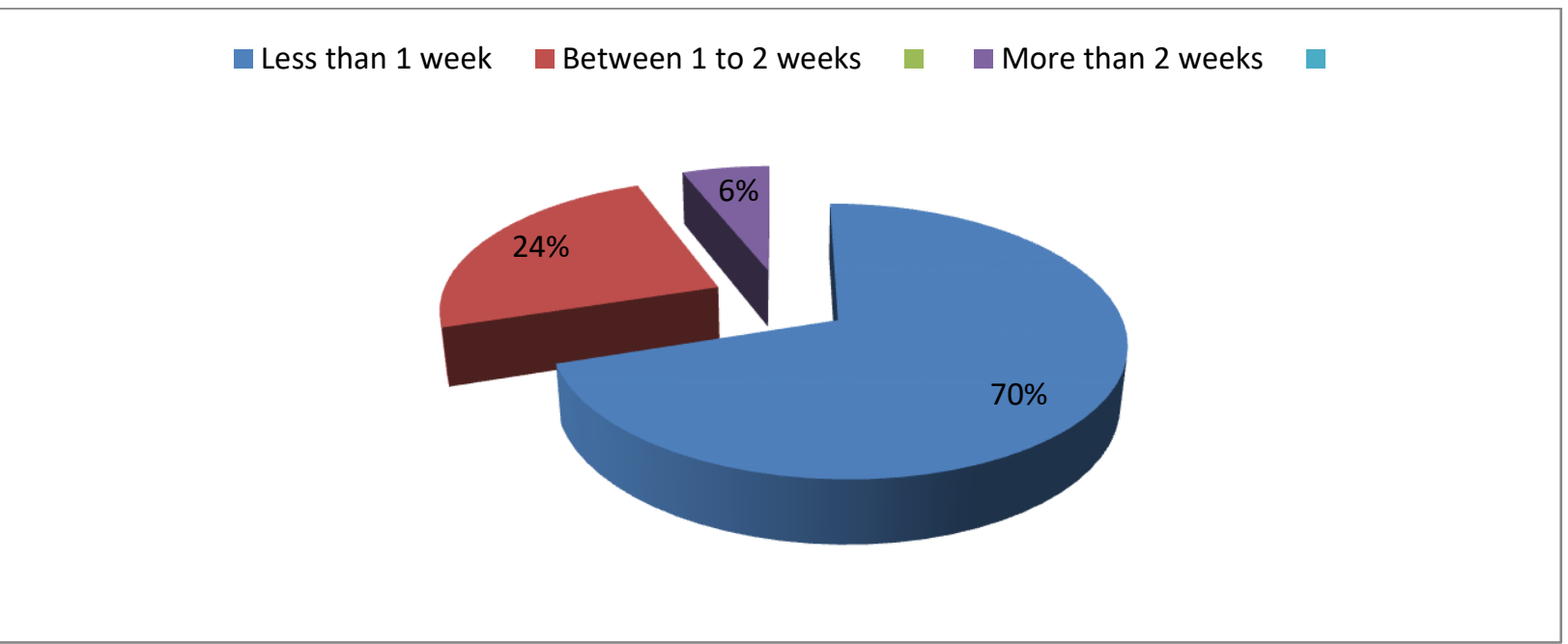

Figure 5: Average time taken for the processing of the loan

Study reveals that $70 \%$ respondents says that average time taken for processing of the loan is less than 1 week, $24 \%$ says that it takes 1 to 2 week and $6 \%$ says that it takes more than 2 weeks.

Table 6. Ranking of the facilities provided by the Co-op. banks

\begin{tabular}{|l|l|l|}
\hline Rank the facility & No. of respondent & Percentage (\%) \\
\hline Above average & 20 & $40 \%$ \\
\hline Average & 25 & $50 \%$ \\
\hline Below average & 5 & $10 \%$ \\
\hline
\end{tabular}


International Journal of Research in Advent Technology, Vol.7, No.1, January 2019 E-ISSN: 2321-9637

Available online at www.ijrat.org

Above average $\square$ Average $\square$ Below average

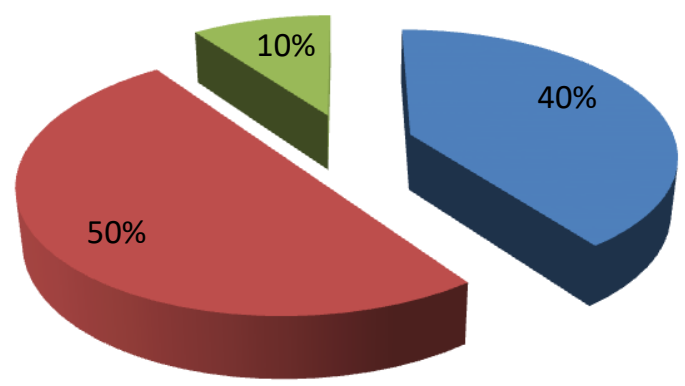

Figure 6: Ranking of the facilities provided by the Co-op. banks

Study shows that $50 \%$ of the respondent says that facility provided by the cooperative bank are average, $20 \%$ say that its above average and $5 \%$ says that its below average.

Table 7: Preferable Banks provides innovative products and services

\begin{tabular}{|l|r|r|}
\hline Preferable banks in future & No. of respondent & Percentage (\%) \\
\hline Public banks & 22 & 44 \\
\hline Private banks & 18 & 36 \\
\hline Cooperative bank & 10 & 20 \\
\hline
\end{tabular}

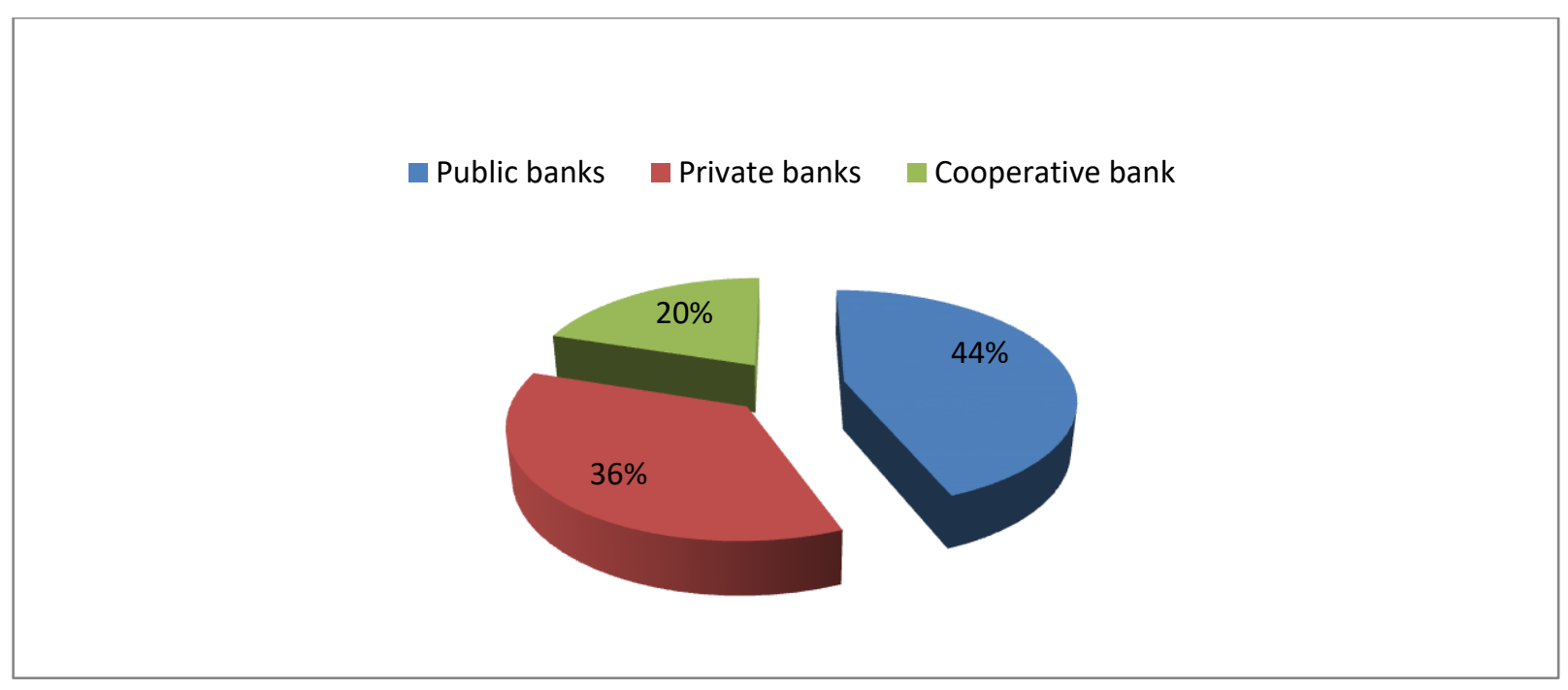

Figure 7: Preferable Banks provides innovative products and services 
Study shows that $44 \%$ of the respondent says that public sector banks offer innovative products and services,36\% says private sector and $20 \%$ respondents says cooperative banks provide innovative products and services.

Table 8: Preferable banks for borrowing facilities

\begin{tabular}{|c|c|c|}
\hline Preferable banks in future & No. of respondent & Percentage (\%) \\
\hline Public banks & 15 & $30 \%$ \\
\hline Private banks & 7 & $14 \%$ \\
\hline Cooperative bank & 28 & $56 \%$ \\
\hline
\end{tabular}

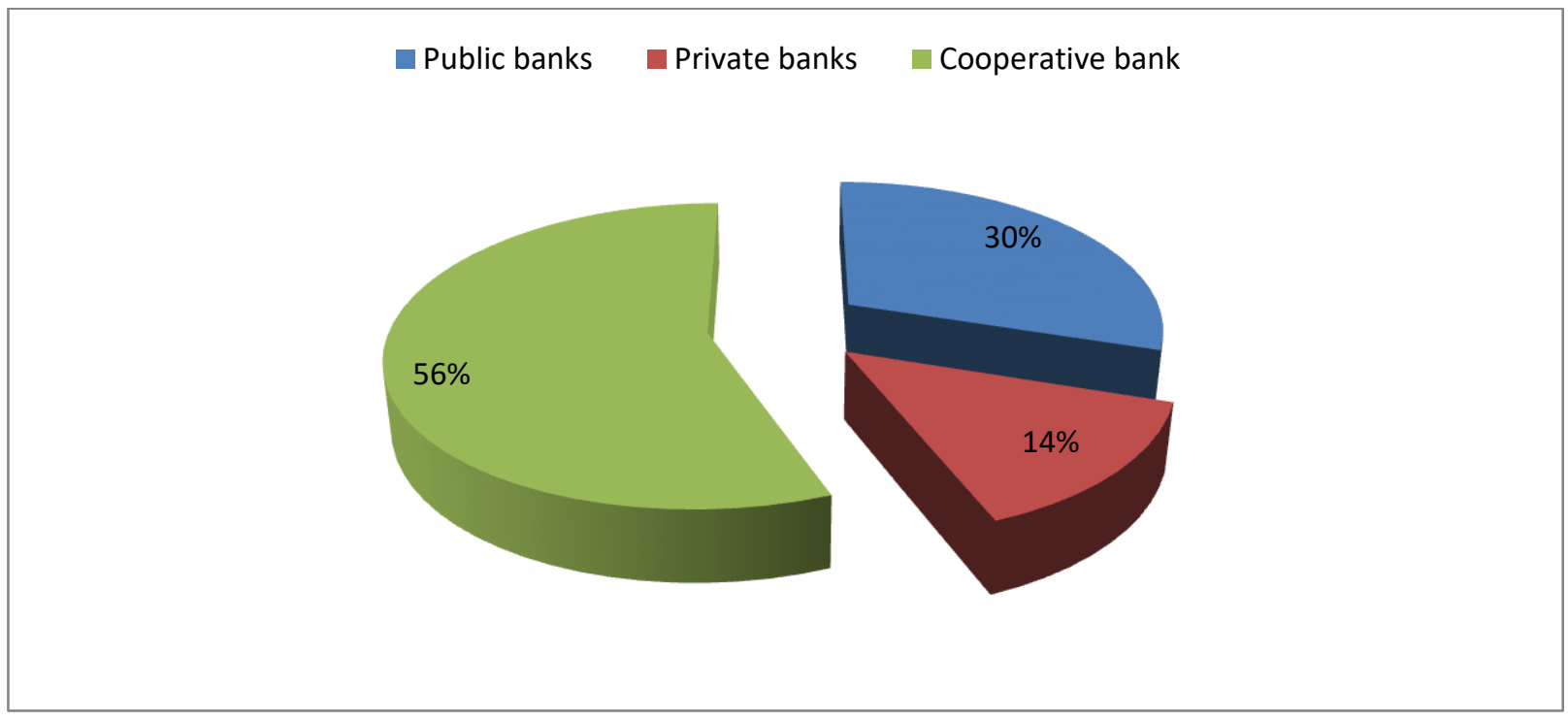

Figure 8: Preferable banks for borrowing facilities

Study shows that $56 \%$ of the respondents will prefer loans from co-operative banks,30\% from the public banks and $14 \%$ from the public banks

Table 9: Preferable Banks and their staff's modesty with customers

\begin{tabular}{|c|c|c|}
\hline Preferable banks & No. of respondent & Percentage (\%) \\
\hline Public banks & 10 & $20 \%$ \\
\hline Private banks & 10 & $20 \%$ \\
\hline Cooperative bank & 30 & $60 \%$ \\
\hline
\end{tabular}




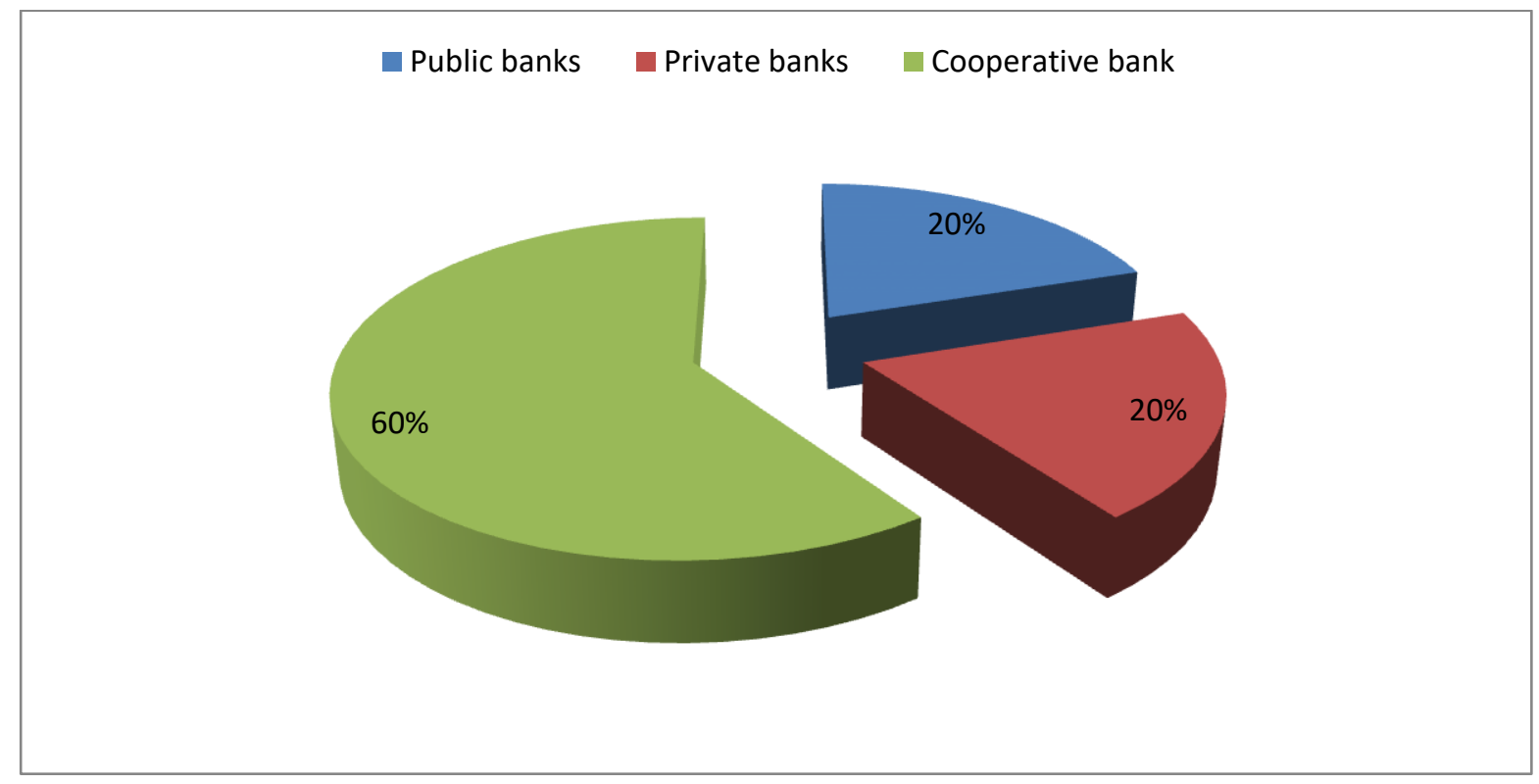

Figure 9: Preferable banks and their staff's modesty with customers

Study shows that $60 \%$ of the respondents says that staff modesty of cooperative banks is satisfactory. based in all the 12 districts in Himachal Pradesh. This suggests that efforts need to be taken to improve banking penetration in all the districts of Himachal along with more focus on ground level quality services.

\section{FINDINGS OF THE STUDY}

1. Majority (32\% as per the study) of the respondent were having agricultural loan from this bank.

2. Most (64\% as per the study) of the people prefer to take long term loan which is more than 3 years.

3 . Easy repayment ( $50 \%$ as per study) and less formality are the essential factors determining customer's selection of loans from cooperative banks.

4. There is a very simple procedure followed by bank related to loan process.

5. The Cooperative bank's staff (60\% as per study) is very courteous with customer as compared to public and private banks because cooperative banks staff understand the customer very well.

6. Cooperative banks understand the core need of local customers and offers innovative products and services accordingly.

7. Average time for the processing of loan is less i.e approx 7 days.

The financial positions of HP state Cooperative bank and Kangra Central Cooperative banks improved in 2016-2017 though there are some concerns with regard to financial performance due to increasing existence of Public and private sector banks in rural areas. Although it was observed that the branch network of cooperatives banks in Himachal is limited only to some large districts .Moreover, the network of cooperatives was not broad Top management of the bank should focus on increasing market share, increase branches of the bank in rural and urban areas. Bank will also adopt new banking technologies to attract and retain old customers; it will help for making profit.

\section{SUGGESTIONS}

1. The banks should plan for the expansion of branches in all over the state.

2. The banks should adopt and also aware customers the benefits of modern methods of banking like internet banking, Mobile banking and ATM, etc.

3. The banks should plan to introduce new schemes for attracting new customers and satisfying the needs of present customers.

4. The banks should improve their prompt services on loan process.

\section{CONCLUSION}

In a state like Himachal Pradesh, where maximum people's involved in agriculture \& Horticultural the co operative is of great importance because it is an organization established for the poor, illiterate and unskilled people for their mutual help and sharing means of development and to overcome the constraints of agricultural development because agriculture has its maximum contribution in financial income. Cooperative 


\section{Available online at www.ijrat.org}

banks can play much better role in the development of state with increase branches of the bank in rural areas. Bank will also adopt new banking technologies to attract and retain old customers; it will help for making profit and also increase saving habits of rural people.

\section{REFERENCES}

[1] Barwal N. and Kumar K.(2015), "Conceptual Study on Human Resources Development Practices in India Services Sector" Research article International Journal of Innovative and Applied Research.

[2] Justin Paul and Padmalatha Suresh (2008),"Management of Banking and Financial Services", Second impression, Dorling Kindersley (India) Pvt. Ltd., PHI, Chapter: 6, 78-116.

[3] Shiang-Tai Liu (2009), "Slacks-based efficiency measures for predicting bank performance", Graduate School of Business and Management, Vanung University, Chung-Li, Taiwan.

[4] Vijay Mavaluri, Pradeep Boppana and Nagarjuna (2006), "Measurement of efficiency of banks in
India" University Library of Munich, Germany, MPRA Paper 17350, Aug 2006.

[5] Barwal, N and Kumar, K (2015), "Comparative performance evaluation on Himachal Pradesh Cooperative Bank and Kangra central Cooperative Bank", International Journal of Scientific Research and Management, vol.3, Issue 7, pg 3316-3323

[6] Rao, K. V. And Nirmala, D. (2006). Performance evaluation of urban co-operative banks. The Indian Journal of Commerce: Indian Commerce Association, 36-50.

[7] Ravindra, P.S and Murthy, Narayan 2013, „Performance Evaluation of Urban Co-operative Banks in India ${ }^{e e}$, Advances in Management, Vol. 6 (10) October, pp. 34-39.

[8] Reddy and Prasad 2011, "Evaluating performance of RRBs: An application of CAMEL model", Journal of Arts, Science \& Commerce, Vol. II issue 4, Oct 2011.

[9] Annual reports of Himachal Pradesh State Cooperative Bank Ltd \& Kangra Central Cooperative banks (2016-2017) 